International

Medical Society

http://imedicalsociety.org
International Archives of Medicine

SeCtion: Medical Education

ISSN: 1755-7682

Vol. 9 No. 229

doi: $10.3823 / 2100$

\section{Using the Questioning Method in the Training Nursing Professionals ORIGINAL}

\section{Abstract}

Education is a strategy within society to facilitate that each individual may reach their full potential, and to encourage them to collaborate with others in actions aimed at the common well-being. The objectives were to analyze scientific knowledge production on questioning method and its use in nursing education. The methodological strategy was the integrative review. Using the combinations among the keywords: questioning methodology and nursing. Data were dealt with from the technique of content analysis in the thematic analysis modality. 19 articles were analyzed where they rectify the interface between using the questioning methodology and nursing education and describe the factors associated to this theme. Even considering the questioning methodology as a viable path in the current context, there must be a constant commitment in reviewing the used processes, in order to highlight the strengths and weaknesses, with views to their improvement.
Girzia Sammya Tajra Rocha1,2, Benevina Maria Vilar Teixeira Nunes ${ }^{1,3}$, Elizabeth Soares Oliveira de Holanda Monteiro ${ }^{1,4}$, Lourival Gomes Silva Júnior 1,5

1 Post-Graduate Program in Nursing/ PPGENF, Federal University of Piauí/ UFPI. Teresina (PI), Brazil.

2 Collegiate of Nursing - Binational Campuses of Oiapoque. Federal University of Amapá/UNIFAP. Rodovia BR 156, n 3051. Quarter: University Oiapoque-AP. CEP 68.980-000.

3 Department of Nursing. Federal University of Piauí/UFPI, Teresina (PI), Brazil.

4 Estácio College - CEUT, Teresina (PI), Brazil.

5 Federal Institute of Piauí, Valença (PI), Brazil.

Contact information:

Elizabeth Soares Oliveira de Holanda Monteiro.

Đ elizahm@terra.com.br

Keywords

Teaching; Education in Nursing; Learning.

\section{Introduction}

Education is a strategy within society to facilitate that each individual may reach their full potential, and to encourage them to collaborate with others in actions aimed at the common well-being. Considerable part of unevenness between individuals, organizations, regions and countries is due to inequality of chances relative to developing the capacity to learn and materialize something new (1).

Historically, education in the health field has been guided by using traditional methods, derivatives from mechanist and Cartesian models that are conservative education and learning proposals, 
where the teacher is placed in the center of the educational process as a content transmitter and the student acts as a passive spectator (2).

However, we live in a society that recognizes, internationally, the need to modify traditional education, due to its incapacity to satisfy the population needs. However, for this transformation day, the solid barriers must be broken to move what it is taken root in time ${ }^{(1)}$

In this context, questioning methodology is used to break with the paradigm on the traditional education and base-related concepts of Pablo Freire, with conscience that define the way for building the autonomy and the emancipation, the ethics, the commitment, the dialogue, the questioning, that together construct what it called emancipatory education (3)

As well as in the studies of Diaz Bordenave and Pereira, who are based on the arc of Maguerez and propose a reality questioning scheme in five steps: observing reality; identifying key points; theory; hypotheses of solution and application to reality. This approach aims at making the professionals more reflective, interrogative and capable to team work team (4).

In the nursing area the questioning methodology emphasizes the importance to construct knowledge from the practiced experiences. These are emergent properties that stimulate the student to adapt a new perspective in relation to themselves, to the others and to the relation of care and health practices. In this form, it is used in situations where the themes are related with life in society and consists in a methodological way capable to guide the pedagogical practice of an educator worried about the development of its students and with their intellectual autonomy, with the purpose of developing the critical, creative and reflective thought, beyond the preparation for a political performance ${ }^{(1)}$.

This study aims to analyze scientific knowledge production on questioning method and its use in nursing education.

\section{Methodology}

We opted for the integrative revision of literature, that has as a purpose the systematization of research results on a determined thematic, in a clear, objective and systematic way that makes possible the synthesis of the state of knowledge on a determined subject, in order to contribute for deepening the searched subject, in addition to pointing out gaps of knowledge that need to be filled out with the accomplishment of new studies.

Literature integrative review consists of an ampler method, that allows for combining data from theoretical and empiric literature. This type of research has different objectives, such as: it may be directed to concept definition, theories review or methodological analysis of included studies for a particular topic ${ }^{(5)}$.

There followed the methodological path in six steps proposed by Mendes, Silveira and Galvão (6), which consists on the following steps: identifying the theme and selecting the hypothesis that is matter of the research; setting up criteria for inclusion and exclusion of studies; defining the information to be extracted from selected studies/categorization of studies; assessing studies included in the integrative review; interpreting the results; and, submitting knowledge review/synthesis.

This study's guiding question as formulated initially, where the guiding question on the revision process was constructed through peak strategy ( $P$ $=$ Patient or Problem, I = Intervention, $\mathrm{C}=$ Comparison or control, $\mathrm{O}=$ Outcomes or results) (6). What scientific knowledge has been produced on the questioning method and its use in teaching nursing?

Following on, the criteria for including articles to begin the sampling process in the literature were established, and the criteria were: articles published in indexed journals, available in the entirety, published in Portuguese, English and Spanish languages. Those should primary researches and theoretical 
studies, and treating the nursing education based on the questioning method. Such being the case, theses and dissertations were excluded from the study and also articles not containing elements to answer the guiding question.

The investigation occurred in July and August, 2015. For the bibliographic survey, the controlled descriptors found in the Health Science Descriptors (HSD)" questioning method" and "nursing" were used. The used databases were the following: Literatura Latino-Americana e do Caribe em Ciências da Saúde (LILACS), National Library of Medicine (MEDLINE), Scientific Electronic Library Online(SCIELO), Base de Dados de Enfermagem (BDENF) and Portal de Periódicos CAPES/MEC.

To operationalize the search, diverse key-word combinations were conducted from the use of the and Boolean marker, as described in Table 1.

The search on the electronic databases LILACS, MEDLINE, Portal de Periódicos CAPES/MEC, SCIELO and BDENF, provided for the acquisition of 19 primary studies, for sample composition of this integrative review.

Portal de Periódicos CAPES/MEC, From the keyword combination, 29 studies were identified in Lilacs, 45 in Portal de Periódicos CAPES/MEC, one in
Table 1. Used databases, with the list of key-word combinations for searching primary articles. Teresina - PI, 2015.

\begin{tabular}{l|l|}
\multicolumn{1}{c|}{ Database } & \multicolumn{1}{c|}{ Key-word combinations } \\
\hline LILACS & Questioning method and nursing \\
\hline MEDLINE & Questioning method \\
\hline $\begin{array}{l}\text { Portal de Periódicos } \\
\text { CAPES/MEC }\end{array}$ & Questioning method and nursing \\
\hline SCIELO & Questioning method \\
\hline BDENF & Questioning method \\
\hline
\end{tabular}

Medline, 25 in Scielo and 22 in Bdenf. Initially, the first selection of studies was carried out by reading the title and abstract, in order to verify compliance with the inclusion criteria. After this first survey, the first selection was conducted with the inclusion of seven articles in Lilacs, two in Portal de Periódicos CAPES/MEC, one in Medline, three in Scielo, and six in BDENF. The repeated articles and that did not meet the inclusion in the searched bases were excluded.

In Figure 1 there is a literature flow-chart for the bibliographic survey in the databases LILACS, MEDLINE, Portal de Periódicos CAPES/MEC, SCIELO and BDENF.

Figure 1: Mapping for outcome identification, analysis and selection. Teresina, 2015.

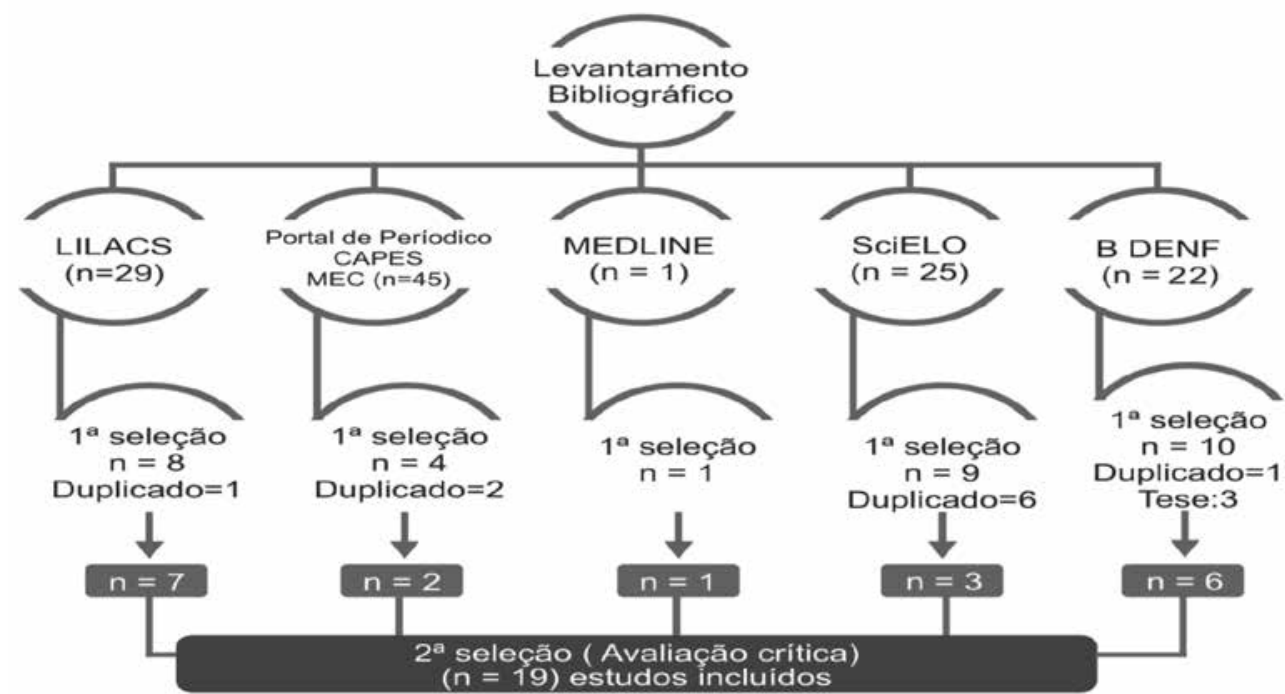




\section{Results}

\section{Characteristics of included studies}

The analyzed studies 19 ratify the interface between using the questioning methodology and nursing education, as they describe the factors associated to this theme. The theoretical studies support this discussion are displayed in Table $\mathbf{2}$.

It is observed that the production of scientific knowledge that approaches the use of the questioning method in the nursing education shows publications between the years from 2000 to 2014 being distinguished a larger number in the years: 2012, 2013 and 2014.

As for the methodological approach for the selected studies, the qualitative approach, experience report, theoretical reflection and research-action were highlighted. In relation to the journals, 12 of the studies are found published in nursing magazines and 7 in other area magazines.

The target-audience and the thematic approach for the publications are directed toward using the questioning methodology in the nursing education, having been this education directed both toward students, as well as toward patients through educative actions.

And the level of scientific evidence for the studies was analyzed in accordance with its hierarchic classification of the evidences, for evaluating researches or other sources of information that is based on categorization from the Agency for Healthcare Research and Quality (AHRQ) from the United States of America.

The quality of the evidences is classified in seven levels, namely: level 1, the evidences are proceeding from systematic revision or meta-analysis for all relevant, randomized, controlled clinical essays or deriving from clinical directives based on systematic revisions of controlled, randomized clinical assays; level 2, evidences derived from at least one well delineated, controlled, randomized clinical assay; level 3, evidences obtained from well delineated clinical assays without randomization; level 4, evidences proceeding from well delineated cohort and case-control studies; level 5, evidences originated from systematic revision of descriptive and qualitative studies; level 6, evidences derived from just one descriptive or qualitative study; level 7, evidences deriving from opinion of authorities and/or report of committees of specialists (6)

In the analyzed studies the level of evidence ${ }^{6}$ was predominant, where all studies displayed a descriptive or qualitative approach.

\section{Discussion}

After recognizing the significance units repeated throughout the texts, the analysis of the gotten material pointed out for three main directions: using the questioning methodology, both in education for students as well as in the assistance using the education in health and a bigger concern, discussion and use by the professional nurses in the recent years, in the attempt to breach with the paradigm of the traditional education.

The studies that approach this theme show specific characteristics as per accomplished analysis, therefore using the questioning methodology is verified in order to construct the knowledge through lived experiences.

Implementing new teaching-learning models has been happening and arising more visibility and interest from the Brazilian researchers, the influence of the traditional education method, centered in the professor and the contents is still strongly verified in the daily activity of those that are proposed to be educators in the health area.

It can be observed that innovative ways were pointed out with respect to the training and qualification of professionals, in order to qualify them in the technical, ethical and political aspects for transforming the working process based on the fragmented care principles. 
Table 2. Characterization for studies, as for author, year, journal, methodology, target audience, thematic focus and level of evidence.

\begin{tabular}{|c|c|c|c|c|c|}
\hline $\begin{array}{l}\text { Author, } \\
\text { year }\end{array}$ & Journal & Methodology & Target-Audience & Thematic approach & $\begin{array}{l}\text { Level of } \\
\text { Evidence }\end{array}$ \\
\hline $\begin{array}{l}\text { Valente; } \\
\text { Saboia, } \\
\text { Gomes et al, } \\
2012^{(7)}\end{array}$ & $\begin{array}{l}\text { Rev. Pesquisa } \\
\text { Cuidado é } \\
\text { Fundamental } \\
\text { online }\end{array}$ & $\begin{array}{l}\text { Descriptive } \\
\text { experience report, } \\
\text { with qualitative } \\
\text { nature }\end{array}$ & $\begin{array}{l}\text { Community that } \\
\text { attended the unit in the } \\
\text { second half of } 2011\end{array}$ & $\begin{array}{l}\text { Description of the involvement } \\
\text { of nursing professionals on } \\
\text { Dengue in an Educational action } \\
\text { in a Polyclinic in the city of } \\
\text { Niterói RJ }\end{array}$ & VI \\
\hline $\begin{array}{l}\text { Ferreira; } \\
\text { Silva; Sousa } \\
\text { et al, } 2012^{(8)}\end{array}$ & $\begin{array}{l}\text { Rev. Min. } \\
\text { Enferm. }\end{array}$ & $\begin{array}{l}\text { Exploratory, } \\
\text { qualitative study }\end{array}$ & $\begin{array}{l}\text { Sample of } 21 \text { masculine } \\
\text { gender adolescents from } \\
\text { the } 7 \text { th to } 9 \text { th grade } \\
\text { of afternoon primary } \\
\text { education }\end{array}$ & $\begin{array}{l}\text { Build up knowledge about } \\
\text { preventing STD/HIV/AIDS based } \\
\text { on cultural and religious aspects, } \\
\text { using Paulo Freire methodology }\end{array}$ & VI \\
\hline $\begin{array}{l}\text { Martin; } \\
\text { Rodrigues; } \\
\text { Cesarino, } \\
2011^{(9)}\end{array}$ & $\begin{array}{l}\text { Rev. Enf. } \\
\text { UERJ. }\end{array}$ & $\begin{array}{l}\text { Cross-sectional, } \\
\text { descriptive study }\end{array}$ & $\begin{array}{l}\text { Sample of } 52 \text { Diabetic } \\
\text { Patients from a teaching } \\
\text { Hospital, in SP inland } \\
\text { region }\end{array}$ & $\begin{array}{l}\text { Evaluate the knowledge of } \\
\text { diabetic patients before and } \\
\text { after educational activity on the } \\
\text { foot care using the questioning } \\
\text { method. }\end{array}$ & VI \\
\hline $\begin{array}{l}\text { Nakatani; } \\
\text { Carvalho; } \\
\text { Bachion, } \\
2000^{(10)}\end{array}$ & $\begin{array}{l}\text { Rev Latino } \\
\text { Am. Enferm }\end{array}$ & Research-action & $\begin{array}{l}\text { Students enrolled in the } \\
\text { 2nd year of the Nursing } \\
\text { Care Methodology } \\
\text { course in } 1998 .\end{array}$ & $\begin{array}{l}\text { Implement and analyze lung } \\
\text { physical examination teaching } \\
\text { through the questioning } \\
\text { method. }\end{array}$ & VI \\
\hline $\begin{array}{l}\text { Borille; } \\
\text { Brusamarello; } \\
\text { Paes et al, } \\
2012^{(11)}\end{array}$ & $\begin{array}{l}\text { Texto-Cont } \\
\text { Enferm }\end{array}$ & $\begin{array}{l}\text { Experience and } \\
\text { quantitative } \\
\text { research report }\end{array}$ & $\begin{array}{l}\text { Workers of psychiatry } \\
\text { specialized hospital }\end{array}$ & $\begin{array}{l}\text { Report the experience of } \\
\text { applying Arc Questioning } \\
\text { Method }\end{array}$ & VI \\
\hline $\begin{array}{l}\text { Rezende; } \\
\text { Takeda; } \\
\text { Fraga et al, } \\
2006^{(12)}\end{array}$ & Interface & Experience report & $\begin{array}{l}\text { Professors of the nursing } \\
\text { course }\end{array}$ & $\begin{array}{l}\text { Report the development of the } \\
\text { education plan throughout the } \\
\text { four series of nursing course, } \\
\text { pointing out reflections on the } \\
\text { pedagogical practice }\end{array}$ & VI \\
\hline $\begin{array}{l}\text { Barbosa; } \\
\text { Aires; Farias } \\
\text { et al } 2013^{(13)}\end{array}$ & Braz & $\begin{array}{l}\text { Quase- } \\
\text { experimental } \\
\text { study with time- } \\
\text { series delineation }\end{array}$ & $\begin{array}{l}\text { Sample of } 82 \text { nursing } \\
\text { professionals (nurse, } \\
\text { nursing technician, } \\
\text { nursing assistant) that } \\
\text { work in hosp. }\end{array}$ & $\begin{array}{l}\text { Check the knowledge of nursing } \\
\text { professionals after educative } \\
\text { actions in infantile auditory } \\
\text { health }\end{array}$ & VI \\
\hline $\begin{array}{l}\text { Burgatti; } \\
\text { Bracialli; } \\
\text { Oliveira, } \\
2013^{(14)}\end{array}$ & Rev. Enf. USP. & $\begin{array}{l}\text { Exploratory study } \\
\text { of qualitative } \\
\text { approach }\end{array}$ & $\begin{array}{l}\text { Sample of } 28 \text { students, } \\
\text { professors and nurse } \\
\text { collaborators of a } \\
\text { higher education public } \\
\text { institution in of SP }\end{array}$ & $\begin{array}{l}\text { Analyze the repercussion on } \\
\text { the supervised curricular period } \\
\text { of training in the development } \\
\text { of the ethical dimension for } \\
\text { the ability of under-graduation } \\
\text { students in nursing }\end{array}$ & VI \\
\hline $\begin{array}{l}\text { Pereira, } \\
2012^{(15)}\end{array}$ & $\begin{array}{l}\text { Ciência y } \\
\text { Enfermeria } \\
\text { XVIII }\end{array}$ & $\begin{array}{l}\text { Theoretical } \\
\text { reflection }\end{array}$ & Nursing & $\begin{array}{l}\text { Understand some aspects on } \\
\text { knowledge production process } \\
\text { in nursing in a de-centered and } \\
\text { adverse context }\end{array}$ & VI \\
\hline
\end{tabular}


Table 2. Cont.

\begin{tabular}{|c|c|c|c|c|c|}
\hline $\begin{array}{l}\text { Author, } \\
\text { year }\end{array}$ & Journal & Methodology & Target-Audience & Thematic approach & $\begin{array}{l}\text { Level of } \\
\text { Evidence }\end{array}$ \\
\hline $\begin{array}{l}\text { Silva; Dias; } \\
\text { Rodrigues, } \\
2009^{(16)}\end{array}$ & $\begin{array}{l}\text { Ciência } \\
\& \text { Saúde } \\
\text { Coletiva }\end{array}$ & Qualitative & 16 Nurses & $\begin{array}{l}\text { Analyze the educative practice in } \\
\text { health of nurses of Family Health } \\
\text { Strategy of Sobral, Ceará }\end{array}$ & VI \\
\hline $\begin{array}{l}\text { Carácio; } \\
\text { Conterno; } \\
\text { Oliveira; } \\
\text { Marin; } \\
\text { Braccialli, } \\
2014^{(17)}\end{array}$ & $\begin{array}{l}\text { Ciência } \\
\text { \& Saúde } \\
\text { Coletiva }\end{array}$ & $\begin{array}{l}\text { Exploratory, } \\
\text { qualitative study }\end{array}$ & $\begin{array}{l}21 \text { subjects, nurses and } \\
\text { doctors }\end{array}$ & $\begin{array}{l}\text { It analyzes the training of } \\
\text { medical nurses of a public } \\
\text { institution from the city of } \\
\text { Marília for performance in } \\
\text { Primary Care, identifying the } \\
\text { conceptions of the professors, } \\
\text { coordinators and egresses in } \\
\text { relation to the professional } \\
\text { training }\end{array}$ & VI \\
\hline $\begin{array}{l}\text { Rosa; } \\
\text { Mercês; } \\
\text { Marcelino; } \\
\text { Radunz, } \\
2007^{(18)}\end{array}$ & $\begin{array}{l}\text { Ciência } \\
\text { \& Saúde } \\
\text { Coletiva }\end{array}$ & $\begin{array}{l}\text { Qualitative } \\
\text { approach }\end{array}$ & $\begin{array}{l}\text { Ten nurses who worked } \\
\text { in the Chemotherapy } \\
\text { Center }\end{array}$ & $\begin{array}{l}\text { Questioning the development of } \\
\text { nursing consultation with } \\
\text { nurses from the Chemotherapy } \\
\text { Center of Health Institute } \\
\text { specialized in oncologic care. }\end{array}$ & VI \\
\hline $\begin{array}{l}\text { Silveira; } \\
\text { Lunardi; } \\
\text { Martins; } \\
\text { Maia; } \\
\text { Mano; } \\
\text { 2005(19) }\end{array}$ & $\begin{array}{l}\text { Cogitare } \\
\text { Enfermagem }\end{array}$ & $\begin{array}{l}\text { Theoretical } \\
\text { reflection }\end{array}$ & Nursing Team & $\begin{array}{l}\text { Explicit concepts constructed } \\
\text { from Freire that supported a } \\
\text { questioning care practice for } \\
\text { daily activity of nursing work } \\
\text { next to nurses and the nurse } \\
\text { assistants, with views to their } \\
\text { awareness as workers in the } \\
\text { nursing team. }\end{array}$ & VI \\
\hline $\begin{array}{l}\text { Nakatani, } \\
2002^{(20)}\end{array}$ & $\begin{array}{l}\text { Revista } \\
\text { Eletrônica de } \\
\text { Enfermagem }\end{array}$ & $\begin{array}{l}\text { Theoretical } \\
\text { reflection }\end{array}$ & $\begin{array}{l}\text { Students of } 2 \text { nd } \\
\text { year in the Course } \\
\text { of Graduation in } \\
\text { Nursing, enrolled in the } \\
\text { Nursing Assistance of } \\
\text { Methodology discipline }\end{array}$ & $\begin{array}{l}\text { This study aims to analyze the } \\
\text { implementation of a teaching a } \\
\text { proposal for a Nursing Process } \\
\text { through Questioning Pedagogy, } \\
\text { materialized by Arco Method }\end{array}$ & VI \\
\hline $\begin{array}{l}\text { Melo; } \\
\text { Queluci; } \\
\text { Gouvêa, } \\
2014^{(21)}\end{array}$ & $\begin{array}{l}\text { Rev. Esc. } \\
\text { Enferm. USP }\end{array}$ & Research-action & $\begin{array}{l}\text { The study involved } \\
\text { Nursing residents of } \\
\text { the first year of PRMO, } \\
\text { enrolled in } 2012 \text {. The } \\
\text { participants in the } \\
\text { research composed a } \\
\text { young group ( } 23 \text { to } \\
\text { 29-year old), with at } \\
\text { maximum two years } \\
\text { from graduation. }\end{array}$ & $\begin{array}{l}\text { Deepen the knowledge } \\
\text { on practical education in a } \\
\text { multi-disciplinary oncological } \\
\text { residence, coming from the } \\
\text { application of questioning } \\
\text { method with nursing residents }\end{array}$ & VI \\
\hline $\begin{array}{l}\text { Schmltt; } \\
\text { Costenaro; } \\
\text { Rangel; } \\
\text { Ferreira; } \\
\text { Lacerda, }\end{array}$ & $\begin{array}{l}\text { Rev. Bras. } \\
\text { Enfermagem }\end{array}$ & $\begin{array}{l}\text { Qualitative, } \\
\text { descriptive } \\
\text { research }\end{array}$ & $\begin{array}{l}25 \text { families of scholars } \\
\text { participated in the } \\
\text { sample, in the period } \\
\text { from March the May, } \\
2012\end{array}$ & $\begin{array}{l}\text { Describe the contributions } \\
\text { of nursing in scholar family } \\
\text { relations that show alterations in } \\
\text { the behavior and the scholar y } \\
\text { performance. }\end{array}$ & VI \\
\hline
\end{tabular}


Table 2. Cont.

\begin{tabular}{|c|c|c|c|c|c|}
\hline $\begin{array}{l}\text { Author, } \\
\text { year }\end{array}$ & Journal & Methodology & Target-Audience & Thematic approach & $\begin{array}{l}\text { Level of } \\
\text { Evidence }\end{array}$ \\
\hline $\begin{array}{l}\text { Aragão; } \\
\text { Soares, } \\
2014^{(23)}\end{array}$ & $\begin{array}{l}\text { Revista } \\
\text { Portuguesa } \\
\text { de } \\
\text { Enfermagem } \\
\text { de Saúde } \\
\text { Mental }\end{array}$ & Research-action & $\begin{array}{l}\text { Nursing students and } \\
\text { professors }\end{array}$ & $\begin{array}{l}\text { Reflexively socialize the teaching } \\
\text { method in Nursing in the Mental } \\
\text { Care experimented by the } \\
\text { professor-student group, from } \\
\text { the logic of (trans) formation of } \\
\text { the psychosocial paradigm }\end{array}$ & VI \\
\hline $\begin{array}{l}\text { Araújo; } \\
\text { Almeida; } \\
\text { Silva, } \\
2000^{(24)}\end{array}$ & $\begin{array}{l}\text { Rev.Bras. } \\
\text { Enfermagem }\end{array}$ & $\begin{array}{l}\text { Theoretical } \\
\text { reflection }\end{array}$ & $\begin{array}{l}\text { A scholar population } \\
\text { (180) in the age group } \\
\text { of } 13 \text { to } 19 \text { years, in the } \\
\text { period from } 1995 \text { the } \\
1997\end{array}$ & $\begin{array}{l}\text { The study has been developed } \\
\text { from the ideas contained in } \\
\text { the questioning suppositions, } \\
\text { adapted from the "arc } \\
\text { method of Charles Maguerez. } \\
\text { with operationalization in } \\
\text { public health and education } \\
\text { institutions, in the State of Ceará }\end{array}$ & VI \\
\hline $\begin{array}{l}\text { Borille; Paes; } \\
\text { Brusamarell; } \\
\text { Mazza; } \\
\text { Lacerda; } \\
\text { Maftum, } \\
2013^{(25)}\end{array}$ & $\begin{array}{l}\text { Cienc Cuid } \\
\text { Saude }\end{array}$ & Experience report & $\begin{array}{l}\text { Five nurses, one } \\
\text { nursing technician and } \\
74 \text { nursing assistants } \\
\text { participated. Data were } \\
\text { collected during } 32 \\
\text { meetings, by means of } \\
\text { the Questioning Arc } \\
\text { Method }\end{array}$ & $\begin{array}{l}\text { Build up a reference landmark } \\
\text { for nursing care in a psychiatric } \\
\text { hospital. }\end{array}$ & VI \\
\hline
\end{tabular}

New forms of teaching-learning and curricular organization have been adopted in the perspective to integrate theory/practice, teaching/service, the disciplines and the different professions in the health area, in addition to searching to develop the reflection capacity on real problems and formularizing original and creative actions capable to transform social reality ${ }^{(12)}$.

Active learning methodologies that are proposed to breach with the traditional teaching-learning methods have been gaining prominence, the questioning methodology searches to mediate the historical - critical conception of education, and the pedagogical work is inspired in the dialectical historical materialism and finds beddings mainly in Praxis Philosophy and in the Liberating/Questioning Pedagogy of Pablo Freire, the basic axle of all the process relates to the action-reflection-transforming-action (11).

It is still noteworthy that the questioning has the social reality as a starting and arrival point, being a way to reflecting on one's own experience, enabling interventions and transformation of this reality, and also creating opportunities for greater diversity of situations, with many uncertainties, constituting a little-structured learning process (19).

It is highlighted that upon materializing the use of this methodology questioning proposal, some difficulties may be highlighted, and among them the main one is: the lack of previous knowledge on the approached content and a facility: developing self-criticism. Having as main contribution the evaluation of the learning process, where professor and students mange to locally identify the difficulties and facilities promptly ${ }^{(10)}$.

Using the questioning methodology also contributed for humanizing the given care and mobilizes the involved ones for a significant learning of reality, in a dynamic and complex form, the dialogue established in the meetings evidences the thinking of 
the team regarding the context where it is inserted, the relationship with the person, with the institution, with the colleagues and with themselves (11).

Renouncing to any pretension for generalization, the use of such methodology for teaching students in nursing is a viable way in the current context, also disclosing that there must be a constant persistence in revising the used processes, detaching the positive points and fragility points with sights to their improvement.

Education is a social practice and should be disinhibiting and non-restrictive in such a way to stimulate the reflective conscience, in the model of questioning education, the educative actions must value the dialogue, discussion, humanization and the real difficulties for educating.

That way, health in education, may be regarded as a formative process where individuals take on responsibility in preventing and controlling the disease, promoting so their health (8)

There appears the initiative to seek a liberating methodology and above all, emancipatory, as an example of the method proposed by Paulo Freire that was an educator beyond his time, challenged his time with a methodology able to transform the individuals into beings who participate actively in their stories through autonomy, freedom, love, dialogue, with a view to transforming the world through pursuing improvement of life (16).

So for nursing, some Paulo Freire's concepts are very useful, such as: freedom, humanization, awareness, dialogue, culture, critical thinking, ethics, questioning; all these concepts are favorable to the development of health education activities in a transforming perspective for the individual. Therefore, in order to develop health education actions, the professional should strip their claim to own the power and then realize that they are not there to teach, but to provide conditions for the construction of knowledge, along with the subject, where both learn, despite their differences, that they are not reduced to the condition of an object of each other, who teaches learns to teach and who learns teaches to learn (8).

Educational activities propitiate going beyond the chains of Cartesian traditionalism, allowing us a critical-reflexive approach, but that above all, drives to a paradigm shift for educational models' retransformation, focused merely on the unique usefulness and in the reductionism (7).

Dialogue requires a true thinking, a critical thinking, and this does not dichotomize men and world, but see them in continuous interaction, as unfinished beings, men make and remake in the world interaction, object of his praxis transformation with the adoption of free postures for making choices, assuming responsibilities for their actions (16).

So there is a permanent cycle of teaching and learning on a daily basis of the nurse that if embedded consciously enhances the teaching process.

\section{Conclusion}

Analyzing the reviewed studies allowed to identify that new ways for teaching and learning and curricular organization were adopted in order to integrate theory, practice, teaching, service, nursing disciplines, as well as to seek to develop the capacity of reflection on real problems and formulation of original and creative actions that can transform the social reality.

Nursing is a social practice and, as such, is related to society's production and reproduction modes. Therefore, in the initial training of future professionals, innovative paths are pointed out for training and qualifying professionals, in order to capacitate them in the technical, ethical and political aspects for transforming work processes.

Even considering the questioning methodology as a viable path in the current context, there must be a constant commitment in reviewing the used processes, in order to highlight the strengths and weaknesses, with views to their improvement. 


\section{References}

1. Prado ML, Velho MB, Espíndola DS, Hilda Sobrinho S, Backes VMS. Arco de Charles Maguerez: refletindo estratégias de methodology ativa na formação de profissionais de saúde. Esc Anna Nery. 2012; 16(1):172-7.

2. Melo MC, Queluci GC. Problematization methodology in nursing of oncologic education: a descriptive study. Online braz J Nurs, 2012; 11(Suppl 1):500-4.

3. Figaro R, Freire P. Comunicação e Democracia. Comunic Educ. 20(1):1-15.

4. Marin MJS. Aspectos das fortalezas e fragilidades no uso das metodologias ativas de aprendizagem. Rev.bras.educ. med.2010;34(1):13-20.

5. Mendes, KDS, Silveira, RCCP, Galvão, CM. Revisão integrativa: método de pesquisa para a incorporação de evidências na saúde e na enfermagem. Texto contexto - enferm. 2008.17(4): 758-64.

6. Santos CMC, Pimenta CAM, Nobre MRC. The PICO strategy for the research question construction and evidence search. Rev. Latino-Am Enfermagem. 2007 ; 15(3):508-511.

7. Valente GSC, Saboia VM, Gomes HF, Santos NSS, Vignoli AR. Problematização como Estratégia de Educação em Saúde no combate à dengue: um relato de experiência. $R$ pesq. cuid fundam online 2012; 4(4):2987-94.

8. Ferreira AGN, Silva KL, Sousa PRM, Gubert FA, Vieira NFC, Pinheiro PNC. Cultura masculina e religiosidade na prevenção das DST/HIVIAIDS em adolescentes. Rev. Min Enferm, 2012; 16(4): 572-578.

9. Martin VT, Rodrigues CDS, Cesarino CB. Conhecimento do Paciente com Diabetes Mellitus sobre o cuidado com os pés. Rev. enferm UERJ. 2011; 19(4):621-5.

10. Nakatani AYK, Carvalho EC, Bachion MM. O ensino do exame físico pulmonar através do método da problematização. Rev. Latino-Am Enfermagem 2000; 8(6): 117-23.

11. Borille DC, Brusamarello T, Paes MR, Mazza VA, Lacerda MR, Maftum MA A aplicação do método do arco da problematização na coleta de dados em pesquisa de enfermagem: relato de experiência. Texto contexto - enferm. 2012 Mar; 21(1): 209-216.

12. Rezende KTA, Takeda E, Fraga EMV, Braccialli LA, Doreto CMQ, Costa MCG et al. Implementando as unidades educacionais do curso de enfermagem da Famema: relato de experiência. Interface. 2006; 10(20):525-35

13. Barbosa $C P$, Aires JB, Farias IYS, Linhares FMP, Griz SMS. Newborn and infant hearing health education for nursing professionals. Braz j otorhinolaryngol 2013 Apr; 79(2): 226-232.

14. Burgatti JC, Bracialli LAD, Oliveira MAC. Problemas éticos vivenciados no estágio curricular supervisionado em Enfermagem de um currículo integrado. Rev esc enferm USP. 2013; 47(4): 937-42.
15. Pereira WR. A produção de conhecimento em enfermagem em um contexto descentrado e adverso. Ciencia y Enfermeria 2012;18(1):9-16, 2012

16. Silva $C P$, Dias $M S A$, Rodrigues $A B$. Práxis educativa em saúde dos enfermeiros da Estratégia Saúde da Família. Ciênc. saúde coletiva 2009; 14(Suppl1):1453-62.

17. Carácio FCC, Conterno LO, Oliveira MAC, Oliveira ACH, Marin MJS, Braccialli LAD. A experiência de uma instituição pública na formação do profissional de saúde para atuação em atenção primária. Ciênc. saúde coletiva. 2014 July; 19(7): 2133-42.

18. Rosa LM, Mercês NNA, Marcelino SR, Radunz V. A consulta de enfermagem no cuidado à pessoa com câncer: contextualizando uma realidade. Cogitare Enferm 2007; 12(4):487-93

19. Silveira RS, Lunardi VL, Martins CR, Maia AR, Mano PS. Conceptualizando a prática de enfermagem a partir de Paulo Freire. Ciência, Cuidado e Saúde. 2005. 4(2): 156-62.

20. Nakatani AYK. Processo de Enfermagem: uma proposta de ensino através da pedagogia da problematização. Rev.Eletr. Enferm, 2002. 4(2):53-60.

21. Melo MC, Queluci GC, Gouvêa MV. Problematizando a residência multiprofissional em oncologia: protocolo de ensino prático na perspectiva de residentes de enfermagem. Rev.Esc. Enferm USP 2014; 48(4):706-14.

22. Schmitt ACAN, Constenaro RGS, Rangel RF, Ferreira CLL, Lacerda MR. Mudanças no comportamento e desenvolvimento do escolar a partir do cuidado à família. Rev. Bras Enferm. 2013; 66(5): 682-7.

23. Aragão MS, Soares IG. (Trans)formando e ousando o método de ensino em enfermagem no cuidado à saúde mental. Revista Portuguesa de Enfermagem de Saúde Mental, 2014. (12), 5964.

24. Araújo MFM,Almeida MI, SilvaRM.AIDS/educação e prevenção: proposta metodológica para elaboração de jogos educativos. Rev.bras. enferm. 2000; 53(4):607-613.

25. Borille DC, Paes MR, Brusamarell T,Mazza VA, Lacerda MR, Maftum MA. Construção de um marco de referência para o cuidado de enfermagem psiquiátrica.Ciênc. Cuid saúde 2013;12(3):483-91.

Publish in International Archives of Medicine

International Archives of Medicine is an open access journal publishing articles encompassing all aspects of medical science and clinical practice. IAM is considered a megajournal with independent sections on all areas of medicine. IAM is a really international journal with authors and board members from all around the world. The journal is widely indexed and classified Q1 in category Medicine. 